\title{
Numerical model for nonlinear analysis of masonry walls
}

\author{
Modelo numérico para el análisis no-lineal de muros de albañilería
}

\author{
Jaime Campbell (Main Author) \\ U. de La Serena, La Serena (Chile) \\ +56512204279 \\ jcampbel@userena.cl
}

Mario Durán (Corresponding Author)

U. de La Serena, La Serena (Chile)

+56512204279

mduran@userena.cl

Manuscript Code: 541

Date of Acceptance/Reception: 22.04.2017/06.11.2015

DOI: $10.7764 /$ RDLC.16.2.189

\begin{abstract}
A new proposal to represent the in-plane non-linear structural behavior of masonry walls is presented. The proposal has the ability to represent unreinforced, reinforced and confined masonry, considering different configurations. The wall configurations can take into account different dimensions for the wall and sizes for bricks and joints. Additionally, the model is able to consider different bricks, mortar and interface brick-mortar material properties. The most important point in the proposal is the implementation of the joint model. The joint model is defined as a special connection considering two non-linear springs (one longitudinal and one transversal to the joint connected in parallel) and one contact element (connected in series with the springs). This configuration is able to simulate almost all the failure possibilities in the joint. The bricks are implemented considering solid finite elements, taking into account a non-linear material behaviour. The main result of the model implemented in ANSYS is the capacity curve of the wall (top displacement versus base shear). The model was used to simulate the structural behaviour of a group of walls previously tested in laboratory at the University of La Serena and the University of Chile. The results obtained with the proposed model have a good agreement with those obtained in the laboratory tests.
\end{abstract}

Key words: Masonry, nonlinear analysis, pushover analysis.

Resumen

Se presenta una nueva propuesta para representar el comportamiento estructural no-lineal de muros de albañilería cargados en su propio plano. El modelo tiene la capacidad de representar muros de albañilería simple, armada y confinada considerando diferentes configuraciones geométricas y distintos tamaños de ladrillos y juntas. Además, el modelo tiene la capacidad de considerar distintas propiedades de materiales para ladrillos, morteros e interfaces ladrillo-mortero. El aspecto más importante de la propuesta es la implementación del modelo de junta, el cual se define como una conexión especial con dos resortes no-lineales (uno longitudinal y uno transversal a la junta, conectados en paralelo) y un elemento de contacto (conectado en serie con los resortes). Esta configuración es capaz de simular casi todas las formas posibles de falla en la junta. Los ladrillos son implementados como elementos finitos sólidos y un material de comportamiento no-lineal. El modelo es implementado en el software ANSYS, a partir del cual se obtiene, como principal resultado, la curva de capacidad del muro (desplazamiento en el tope versus fuerza en la base). El modelo fue aplicado para simular el comportamiento estructural de varios muros de albañilería previamente ensayados la U. de La Serena y la U. de Chile, obteniéndose buenos resultados.

Palabras clave: Albañilería, análisis no lineal, análisis "pushover".

Introduction

For many centuries and in different ways, masonry is one of the most commonly used and important construction materials around the world. Despite of this, nowadays there is a lack of information and research to characterize its mechanical properties and structural performance.

The problems to adequately define the mechanical properties of masonry are related, amongst other reasons, to the possibility of finding the elements needed to build masonry almost everywhere. This situation makes it possible to build masonry in many different ways, methods and qualities. Because of this, the input parameters to define the mechanical properties of masonry are wide and its properties are many and various.

According to many studies, around $50 \%$ of the world's population lives in earthquake prone areas and the effects of earthquakes worldwide have claimed approximately 8 million lives over the last 2,000 years. Moreover, around $40 \%$ of urban the population lives in houses made of masonry and this number increases in under developed countries. In Chile, for instance, the percentage rises to about 50\% (Lüders, 1990; Santa María, Hube, Rivera, Yepes-Estrada, \& Valcárcel, 
2017). Additionally, unreinforced masonry is responsible for approximately $60 \%$ of human casualties due to structural damage caused by earthquakes all over the world.

Taking these facts into account, it is clear that more research and development about the mechanical properties and structural performance of masonry is needed, in order to improve its safety against seismic demands.

Description of the Problem

In the last decades a new line of research has been defined in the field of earthquake engineering, trying to implement non-linear structural analysis in order to give more accuracy and safety to buildings and consistency between the analysis and design methods. In most of these new methods, the "pushover curve" of a structure is a very important element to be obtained. Having defined this "pushover curve" and considering the seismic demand in the form of a "reduced earthquake spectra", the "performance point" of the structure can be obtained, following the steps given in the different methods. The "performance point" defines the base shear and top displacement reached by the structure during the action of the seismic demand. This point determines the structural situation of the building after the earthquake, and, therefore, a performance evaluation can be made according to some predefined parameters or limit states.

Unfortunately, for masonry there is still no clear model to describe the nonlinear behaviour of this material, because of its complexity and wide variety of forms and, therefore, it is not easy to determine the "pushover curve" of a masonry structure. Some efforts have been made in order to solve this situation, but the results are still not conclusive.

In order to contribute to this research field, in this work a numerical model to characterize the in-plane behaviour of masonry under lateral loads (seismic loads) is developed. The main product of this numerical model is the "pushover curve" of a masonry wall.

State of the Art

As already stated, masonry is a complex material that shows different properties depending on the geometrical disposition and the quality of the constituents (bricks and mortar). Usually, the properties of bricks and mortar are independently defined through experimental tests. These tests are widely described in literature and codes. There are also experimental tests to determine the properties of masonry as a whole, considering a special geometric configuration and quality of materials. These tests are also widely reported in literature and codes (DIN, 1998; INN, 2003; INN, 1997).

\section{Bricks and blocks}

The properties of bricks and blocks vary in a wide range of values, depending on the quality of clay (or concrete in the case of blocks) or manufacture. Additionally, the mechanical behaviour of bricks is not necessarily homogeneous and isotropic (especially for hollow or perforated bricks). This means that the properties are not the same in different directions and are also not the same in tension or compression. Normally, the behaviour of bricks is described as elasticbrittle.

To describe the mechanical behaviour of bricks or blocks, usually a simple compression test is made. In order to have a complete characterization of bricks, normally these tests are made considering different directions (the three orthogonal directions of the block, parallel or perpendicular to holes, for example). From this test the stress-strain curve of the brick is obtained, associated with the direction of the applied load and measured deformation, and characteristic compression strength. To determine the traction strength of bricks, there are tests like the "uniaxial tensile strength test", the "splitting tensile test", the "flexural tensile strength" and the "uniaxial tensile strength of bone-shaped specimens" (only for solid blocks). A typical stress-strain curve for compression in bricks is shown in Figure 1. Types "B", " $\mathrm{M}$ ", "O" and "S" correspond to different brick manufacturers, as indicated by Kaushik, Rai, \& Jain (2007). 


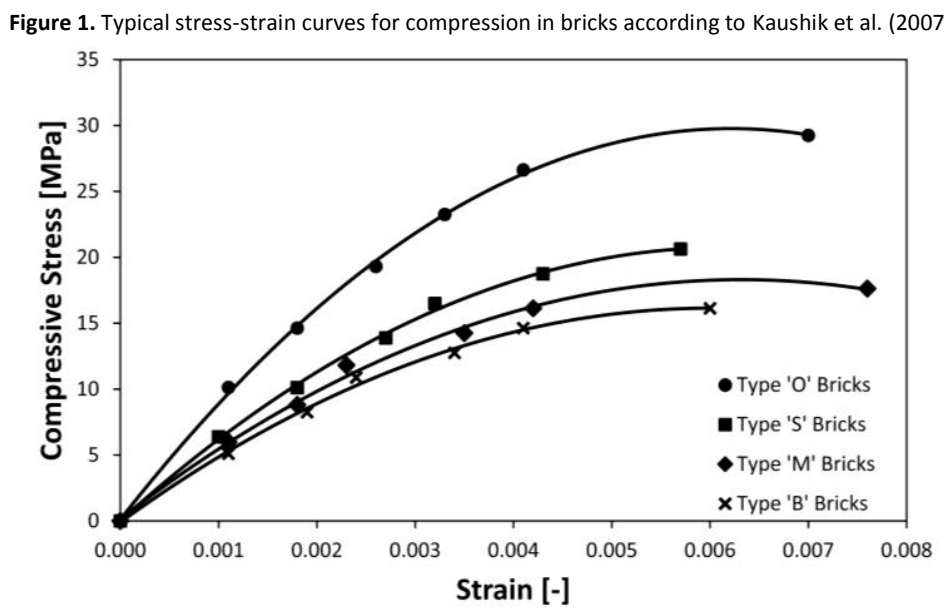

To estimate the elasticity module (Eb) of clay bricks, Kaushik et al. (2007) recommends a range of values depending on the compression strength of the brick ( $\mathrm{fb})$. These values are estimated between 150 and 500 times the compression strength of the brick.

\section{Mortar}

Mortar has many similarities with concrete, but difficulties arise from the different proportion of the components (cement, sand, lime and gypsum), which is the key point in order to determine its mechanical properties. In many cases, it is better to have a good bond between mortar and brick than a high resistance mortar.

To describe the mechanical behaviour of mortar, different tests can be used. The first, and maybe the most typical and important one, is the simple compression test. From this test the stress-strain curve of the mortar is obtained and a characteristic compression strength. To determine the tensile strength of mortar, different tests can be used. Some of these tests are: the "uniaxial tensile strength test", the "splitting tensile test" and the "flexural tensile strength". A typical stress-strain curve for compression in bricks is shown in Figure 2, where three different dosages in terms of cement:lime:sand by volume are presented.

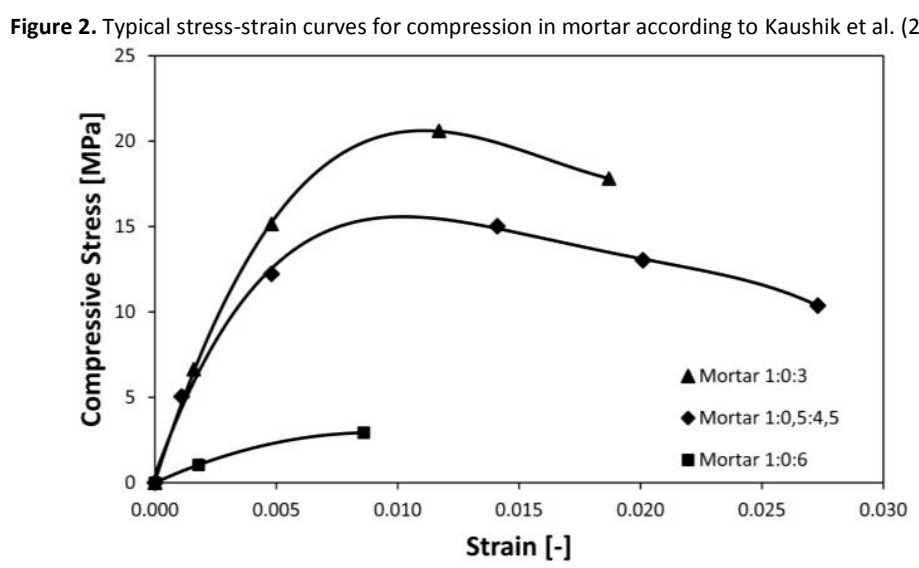

To estimate the elasticity module (Em) of mortar, Kaushik et al. (2007) recommends a range of values depending on the compression strength of the mortar $(\mathrm{fm})$. These values are estimated between 100 and 400 times the compression strength of the mortar.

\section{Contact (interface) between brick and mortar}

The mechanical properties of the contact between brick and mortar can also be estimated from laboratory tests. To determine the tensile behaviour of the interface between brick and mortar, the "tensile bond test" may be used. On the other hand, the estimation of the shear-behaviour of the interface between brick and mortar is made using the "shear bond test". In this test the failure can occur either on the interface or in the mortar. The main result of both tests is the maximum strength (tensile or shear). 


\section{Masonry}

Sometimes it is important to take into account the properties of masonry as a whole. The important thing in these cases is that the interaction between bricks and mortar and the geometrical disposition of the units is considered. In this case, there are many tests which can be carried out. One of these tests is the compression test for masonry prisms, from which a stress-strain curve can be obtained (INN, 2003). Another test to estimate some properties of masonry is the diagonal compression test on wallettes (INN, 1997).

\section{Concrete and reinforcing bars}

In the case of reinforced and/or confined masonry it is also necessary to take into account the quality of concrete and steel. Both of these materials have been widely studied and there is enough information of their properties in codes and literature. In the case of concrete, the compression strength $\left(\mathrm{fc}^{\prime}\right)$ is needed, which is also used to determine the elasticity module (Ec). For steel reinforcing bars, the tensile strength (fy) is needed, and the elasticity module (Es) is considered to be $2.1 \cdot 108 \mathrm{kN} / \mathrm{m} 2$.

\section{Disposition of bricks}

Another important factor to take into account for the determination of the behavior of masonry is the disposition of bricks or type of bond. Masonry is an organized disposition of bricks bonded with mortar and the way the bricks are organized may determine the structural response of the wall. For the model defined in this work, the "running type of bond" will be used. This type of disposition of bricks is the typical in Chile.

\section{Types of masonry}

Depending on the regions of the world, and also the building traditions of the country, masonry has different configurations as a structural element. These configurations vary from unreinforced masonry, to reinforced and confined masonry. The type of masonry used is related to the amount of seismicity, for example in countries with very low seismic activity, unreinforced masonry is used. On the other hand, in countries with mid to high seismic activity, reinforced or confined masonry is used.

Reinforced masonry is a type of masonry that takes into account reinforcement by steel bars embedded in the mortar. This reinforcement is placed in the horizontal joints and/or in the brick holes and then filled with grout. The horizontal reinforcement helps to improve the resistance to horizontal loads (shear failure) and the vertical reinforcement helps to improve the flexural resistance. In seismic countries, this type of masonry is widely used and, sometimes, obligatory.

Confined masonry is a special type of masonry which takes into account the confinement of the masonry within a reinforced concrete frame. This confinement is materialized with vertical tie columns and a horizontal bond beam. Normally, the codes define the requirements for the maximum area to be confined in order to have a good structural performance. In seismic countries, this type of masonry is widely used and, sometimes, obligatory.

\section{Types of models}

According to many authors, there are different possibilities to solve the problem of modeling masonry. These alternatives depend on how detailed is the modeling, and, as a consequence of that, if the model is able to describe accurately different types of failure (Lourenço, 1996; López, Oller Martínez, \& Oñate, 1998). Usually, the alternatives are classified as: detailed micro model, simplified micro model and macro model. 


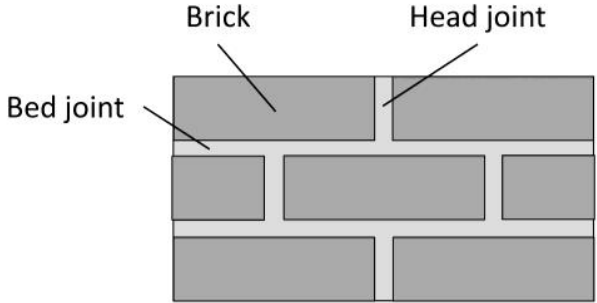

(a)

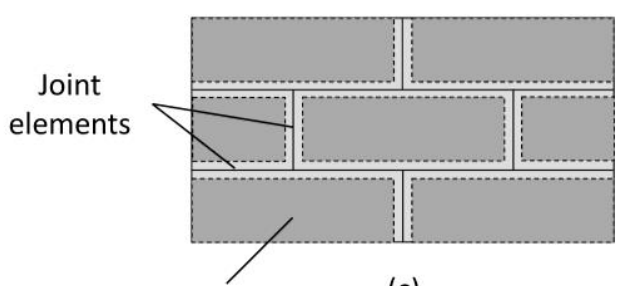

Brick element

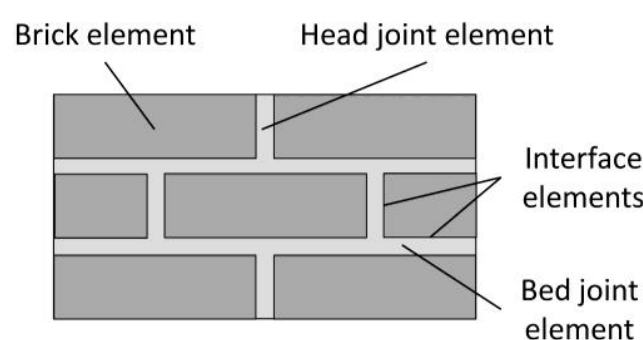

(b)

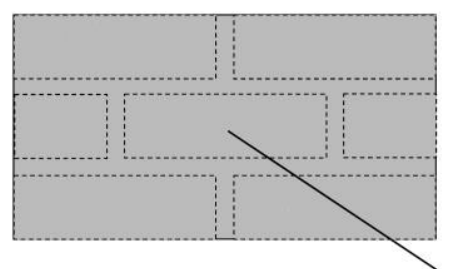

(d)

Composed element

The first alternative in describing a masonry model is the "detailed micro model" (Figure 3 b). This type of modeling considers the bricks and mortar as continuum elements with defined failure criteria. The interface between bricks and mortar is modeled by special elements that represent the discontinuities. In this case, the geometry of the wall is completely reproduced. Because of the level of detail of this model, it is supposed that it can represent most failure mechanisms in masonry.

In the second alternative, the "simplified micro model" (Figure $3 \mathrm{c}$ ), the bricks are kept as in the "detailed micro model", but the mortar joints and interface elements are re-defined as individual elements to represent a contact area. This means that the general geometry is maintained, but the individual elements that represent joints and interface are not able to describe the Poisson's effect of mortar over bricks. Because of this last example, some types of failure mechanisms cannot be reproduced in this type of model.

The last alternative is the "macro model" (Figure $3 \mathrm{~d}$ ). In this case, the masonry panel (or a part of it) is considered as a homogeneous element. Because of its characteristics, this type of model should be able to reproduce the general structural behavior of a masonry panel but it is not able to reproduce all the types of failure mechanisms.

\section{Other proposals to describe the structural behaviour of masonry}

There are many proposals in order to characterize the structural behaviour of the different types of masonry. These proposals require different parameters as input, considering more or less detail in the information related to geometry, quality of brick, mortar or the contact zone between them. They also have different ways to define the models, considering finite elements, non-linear springs, especially defined elements, etc. Moreover, they consider the nonlinearity of the model in a variety of forms, distributed in the elements, concentrated in some of them, etc.

\section{Proposals of Page}

One of the first models to represent the nonlinear behaviour of masonry was proposed by Page (1978). This model considers masonry as a two-phase material which represents brick and mortar. In the case of bricks, these are represented with plane stress quadrilateral finite elements, with eight nodes and four degrees of freedom per node. The element is supposed to have isotropic elastic properties. The elements are chosen quadrilateral, because they fit easily into the typical geometry of masonry. The mechanical properties (modulus of elasticity and Poisson's ratio) of these elements are obtained from laboratory tests on bricks and transformed in order to take into account the thickness of the wall. The mortar joints are represented by linkage elements. This element can only deform in normal and shear directions. The stiffness of these elements is determined minimizing the potential energy with respect to the element displacements. For the determination of the failure criteria for joint elements laboratory tests results are used. In general, these type of elements have a low tensile capacity, a high compression strength and variable shear capacity, which depends on the simultaneous acting compression. 
Page proposed also a finite element model to represent masonry (Page, Kleeman, \& Dhanasekar, 1985). The model is based on a nonlinear material model implemented with a finite element to describe the behaviour of masonry. For the definition of the nonlinear material model, a large number of biaxial tests on half scale brick masonry panels were considered. The panels were tested taking into account different orientations of the bed joint to the edges and a wide range of biaxial stress states. Using the information of the tests on masonry panels, nonlinear stress-strain relationships to reproduce the inelastic behaviour of masonry are derived. These relationships are able to reproduce different forms of failure of masonry, taking into account the orientation of the joints.

\section{Proposals of Lourenço}

In his doctoral research Lourenço (1996) has proposed two models to describe the nonlinear behaviour of masonry. One of these models is a micro model and the other one is a macro model. Amongst the aims of this contribution was to compare the applicability of the two different types of strategies. The micro model is defined through joints which concentrate the inelastic behaviour of the masonry. The plasticity model of the joints is able to reproduce three different types of failure mechanisms: tension cut-off, Coulomb friction model and compression (considering an elliptical cap) and combined shear-compression failure. As a drawback, this type of models requires a huge amount of computational time and memory and, because of that, it is recommended for the study of small structures and structural details.

Taking into account the reasons given in the previous paragraph, Lourenço proposed a second model, specially oriented for the use with large structures. This model is defined by considering an orthotropic continuum model for masonry which takes into account a Rankine type yield criterion for tensile failure (cracking) and a Hill type yield criterion for compressive failure (crushing). This model requires many input parameters related to tension and compression tests in different directions and fracture energy (also in tension and compression).

Proposed Model

In this section, the proposed model to represent the non-linear structural behaviour of masonry walls is described (Campbell, 2012) in terms of a general description, geometry and structural function. The model was completely implemented in ANSYS (ANSYS, 2009), which is a strong software package oriented to solve complex problems in many fields of civil engineering.

\section{Description of the model}

According to many authors (Page, 1978; Lourenço, 1996), mortar and bond between bricks and mortar is responsible for significant nonlinear behaviour of masonry. Following this argument, the most effort in the construction of this model was put on the definition of the type of elements to represent mortar and contact between brick and mortar.

The proposed model could be classified as a "Simplified micro model", according to the definitions given in section 3. This means that bricks are represented by solid finite elements blocks and mortar and bond between bricks and mortar, in this case, are represented by nonlinear springs and contact elements.

The main point in the definition of the model is the representation of horizontal and vertical joints. For this purpose, a group of nonlinear springs and a contact element is used. These elements are combined in order to describe the mechanical and structural behaviour of a typical joint.

The joint model is built using two nonlinear spring elements (connected in parallel) and one contact element (in series with the spring elements), see Figure 4. The two springs represent the axial and transversal behaviour of mortar, respectively, and its properties are directly determined from those of this material. The contact elements represent the bond between brick and mortar and its properties, which are also associated to mortar, but it considers also the friction and the adherence limit between these two elements. The mechanical properties of the springs are determined taking into account the tributary area of the brick over the node.

Obviously, not all possible modes of failure are featured in the proposed model for the joint between bricks and mortar, but the most fundamental ones are covered. 
Figure 4. Detail of the model for joint between bricks and mortar.

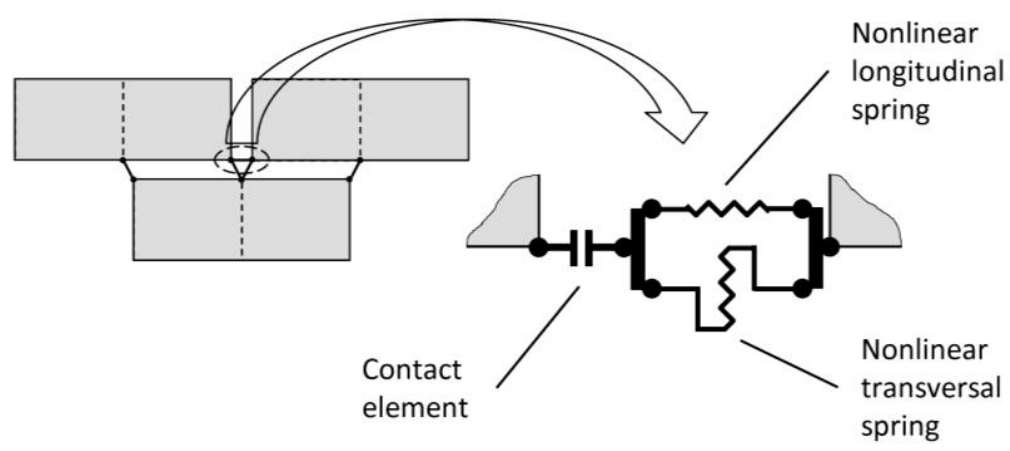

Additionally, the model can reproduce many different alternatives types of masonry and structural situations. It can represent unreinforced, reinforced and confined masonry, as well as different load conditions.

The model is defined using different types of elements to reproduce the structural behaviour of a masonry wall. All elements are defined according to existing elements in ANSYS (ANSYS, 2009). The keypoint is how to combine the different types of elements. In this case, the elements considered to constitute the model are of type "solid finite element", "nonlinear spring element" and "contact element".

In this model, for every type of element, a different type of material (linear or nonlinear) and failure criteria or stressstrain relationship was considered. An important detail is that the model needs as input the mechanical properties of every structural component (bricks, mortar, bond and, eventually, concrete and steel).

\section{Solid elements for bricks and reinforced concrete}

The model considers solid elements to represent bricks and reinforced concrete. These solid elements are of type SOLID65 in ANSYS (ANSYS, 2009). SOLID65 is an element for modeling 3-D solids considering the possibility to include reinforcing bars. The element is a hexahedron with 8 nodes on the corners with 3 degrees of freedom at each node (translations in $\mathrm{x}, \mathrm{y}$ and $\mathrm{z}$ directions) and 8 integration points.

For the implementation of the proposed model, simplified versions of the stress-strain curves for bricks and concrete were considered, modified according to the quality of the materials.

\section{Nonlinear spring elements}

For the modeling of mortar and reinforcing steel bars in masonry nonlinear spring elements were used. For this purpose the element COMBIN39 of ANSYS was chosen. The element is defined as a single bar with two nodes and has up to three degrees of freedom at each node (translations in $x, y$ and $z$ directions). This type of element is a nonlinear unidirectional spring with a generalized multilinear force-deflection law (ANSYS, 2009). The points on this curve represent the internal force in the element versus relative translation between the nodes.

\section{Springs for mortar joints (longitudinal and transversal)}

For the definition of nonlinear springs to represent longitudinal and transversal structural behavior of mortar, the mechanical properties of mortar and the geometry of masonry are used.

In this case, the force-deflection curve of these elements is defined taking into account a simplified version of the stressstrain curve of mortar, the tributary area of the brick over the node and the thickness of the joint. The force for every point of the force-deflection curves is defined considering the stress multiplied by the tributary area (see Figure 5) and the deflection is defined taking into account the strain multiplied by the length of the spring. This length is taken as $9 / 10$ of the thickness of the joint, considering that the length of contact elements is $1 / 10$ of the thickness of the joint. This idea is valid for longitudinal and transversal springs. 


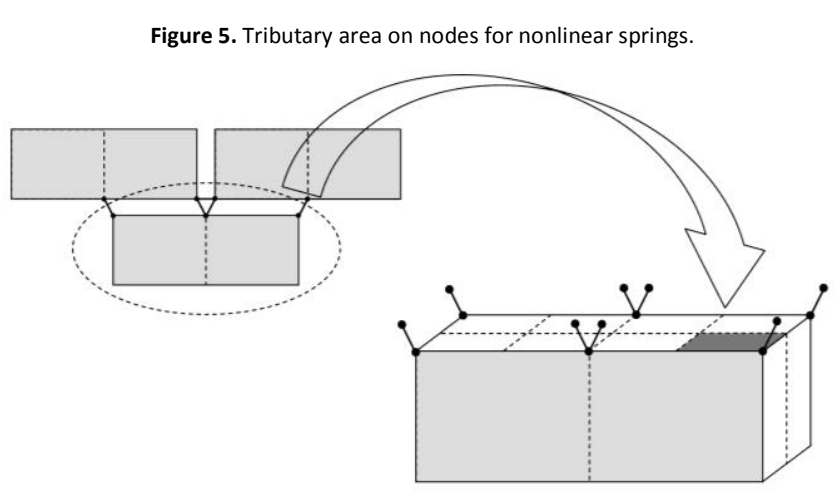

\section{Springs for reinforcing bars in masonry (vertical and horizontal)}

The definition of nonlinear springs to represent vertical and horizontal reinforcing bars in masonry, the mechanical properties of steel are used. In this case, the force-deflection curve of these elements is defined taking into account a simplified version of the typical stress-strain curve of steel and the cross section area of every bar. The force for every point of the force-deflection curves is defined considering the stress multiplied by cross section area and the deflection is defined considering the strain multiplied by the length of the bar. The behavior in tension of mortar is considered linear-elastic up to a stress equal to $1 / 10$ of the compression maximum strength. After this point, the behavior turns to ideal-plastic.

Due to the lack of information regarding to the shear stress-strain behavior of mortar, the shear stress-strain curve was defined similar and proportional to the curve for compression. The maximum shear strength was considered equal to $1 / 10$ of the compression maximum strength. After this point, the behavior turns to ideal-plastic.

\section{Contact elements}

For the modeling of the interface between brick and mortar, node-to-node elements were used. For this purpose the element CONTA178 of ANSYS (ANSYS, 2009) was chosen. This type of element represents contact and sliding between two nodes.

The element is defined by two nodes, an initial gap between the nodes and an initial status of the contact. Each node has up to three degrees of freedom (translations in $\mathrm{x}, \mathrm{y}$ and $\mathrm{z}$ directions). The interface is assumed to be perpendicular to the longitudinal line.

Element CONTA178 has infinite strength and a user defined stiffness in compression (normal to the contact surface). For convergence and stability reasons, stiffness in tension can be regulated as a percentage of the compression stiffness ("weak spring"). The element is able to support friction in the tangential direction (tangential to the contact surface). For this purpose, this element has many options for contact algorithm. In this model, the "Pure penalty method" was chosen.

\section{Interaction between nonlinear springs and contact elements}

The interaction between nonlinear (longitudinal and transversal) springs and contact elements has many advantages for the model in terms of representing in a good way the behavior of the bed and/or head mortar joints.

It is clear that the contact element itself is not able to fail in compression and has no strength in tension. In order to fix this problem, a longitudinal nonlinear spring is connected in series to control the compression and tension capacity of the unit, taking into account a small rigidity in tension of the contact element for stability reasons. The limits of the longitudinal nonlinear spring are determined by the compression capacity of the mortar and by the tension capacity of the mortar and/or the bond strength between brick and mortar.

On the other hand, the contact element connected in series with the transversal nonlinear spring is able to capture the shear failure of the mortar and/or the shear sliding failure between brick and mortar due to adherence deficiency. 
Is important to note that using this configuration of elements to represent the joints, the friction is also limited because compression is limited to the mortar strength, which implies that friction is also limited to this compression strength times the friction factor.

\section{Laboratory Tests}

To make an evaluation of the quality and the accuracy of the proposed model, a group of Chilean laboratory tests made on reinforced and confined masonry walls have been chosen.

The tests were taken from three different research projects, two of which were carried out at the Civil Engineering Department of the University of La Serena (Chile) and the other one at the University of Chile. The projects of the U. of La Serena are one of reinforced masonry walls (Díaz, Arancibia, Vicencio, Durán, \& Campbell, 2005), carried out between years 2004-2005, and one of confined masonry walls (Galleguillos, Valenzuela, \& Díaz, 2010), carried out between years 2008-2009. Finally, the project for confined masonry walls of the University of Chile (Yáñez, Astroza, Holmberg, \& Ogaz, 2004) was carried out between years 2002-2004.

All tests from the U. of La Serena were dynamic and controlled by displacement. The tests were carried out considering a variable horizontal displacement on the top of the wall with a frequency of $0.5 \mathrm{~Hz}$. This displacement was incremented after a pre-determined number of cycles in $0.2 \mathrm{~mm}$ until the wall was sufficiently damaged to stop the test and not until it collapsed. The only vertical load was the self-weight of the walls. The masonry walls are set free at the top.

The tests from the U. of Chile were also dynamic and controlled by displacement. The load was applied horizontally at the level of the bond beam and there was no vertical load applied.

The "pushover curves" are determined from the backbone of the hysteretic cycles and are estimated for both directions (positive and negative) of the tests.

\section{Tests for reinforced masonry walls}

This was a series of tests on three walls (Nr.1, Nr.2 and Nr.3) with identical geometrical and material characteristics and steel reinforcement. The walls were designed according to the provisions given in Chilean code (INN, 2003).

The three walls were made using typical Chilean clay bricks of $75 \times 140 \times 290 \mathrm{~mm} 3$ with vertical holes (MqHv3). The bed and head joints are $1.3 \mathrm{~cm}$ thick with a composition of 4:8:1 (cement:sand:lime). The steel used for reinforcement was type A440-280H. The quality of bricks and mortar was tested for compression according to Chilean codes. The walls are $2.22 \mathrm{~m}$ high (including a top beam of $0.24 \mathrm{~m}$ ) and $1.67 \mathrm{~m}$ long. The vertical reinforcement of each wall is considered with five bars (three $10 \mathrm{~mm}$ diameter plus two $12 \mathrm{~mm}$ diameter at the ends). For more details see Díaz et al. (2005).

\section{Tests for confined masonry walls}

These were two series of tests, one with three walls with the same material characteristics and slightly different geometrical dimensions (U. of La Serena), and the other with two walls with the same characteristics (U. of Chile).

The walls tested at the U. of La Serena (MV1, MV2 and MV3) were designed according to the provisions given in the Chilean code (INN, 1997), considering some special variations in the size of the confining frame. The three walls were made using typical Chilean bricks of 70x140×290 mm3 with vertical holes MqHv3. The bed and head joints are $1.4 \mathrm{~cm}$ thick with a composition of 4:8:1 (cement:sand:lime). The steel used for reinforcement was type A630-420H. The quality of bricks, mortar and concrete was tested for compression according to Chilean codes. Masonry square specimens were also tested for "diagonal compression" in order to determine some general properties. The walls are $2.27 \mathrm{~m}$ high (including a top beam of $0.25 \mathrm{~m}$ ) and $2.20 \mathrm{~m}$ long, including two tie columns of variable width. For more details see Galleguillos et al. (2010).

The walls tested at the U. of Chile (MLC-T1-01 and MCL-T1-02) were considered as reference for a major research project considering masonry walls with openings. The two walls were made using typical Chilean bricks of $115 \times 140 \times 290 \mathrm{~mm} 3$ with vertical holes. The steel used for reinforcement was type A630-420H. The walls are $2.20 \mathrm{~m}$ high (including the top beam) and $3.60 \mathrm{~m}$ long, including the two tie columns. For more details see Yáñez et al. (2004). 


\section{Comparison between model and tests}

The proposed model was implemented and applied to the five walls presented in the previous section. The parameters related to geometry are taken from the information given previously, as well as some other information related to the properties of the materials. The longitudinal elasticity module is estimated according to Kaushik et al. (2007). Other parameters, such as tension and shear strength, and friction and adherence in the contact zone between brick and mortar, are estimated from the tables presented on Mauerwerk Kalender (Irmschler, Schubert, \& Jäger, 2004) for the different types of bricks and mortar of every wall. The comparison is made in terms of the original pushover curves generated by the model and those obtained in the laboratory tests (backbone of the hysteretic cycles) and also for the curves after a bilinearization process. The bilinearization process is made according to the recommendations of FEMA273 (FEMA, 1997). In Figures 6 to 10 the original pushover curves from tests (positive and negative directions) and model for the reinforced walls (Nr. 1, 2 and 3), walls MV1, MV2 and MV3, and walls MLC-T1-01 and MLC-T1-02 are shown. The dashed horizontal line is the nominal shear force calculated according to MSJC (The Masonry Society, 2003). In Tables 1 to 8 the main parameters for bilinear curves are compared.

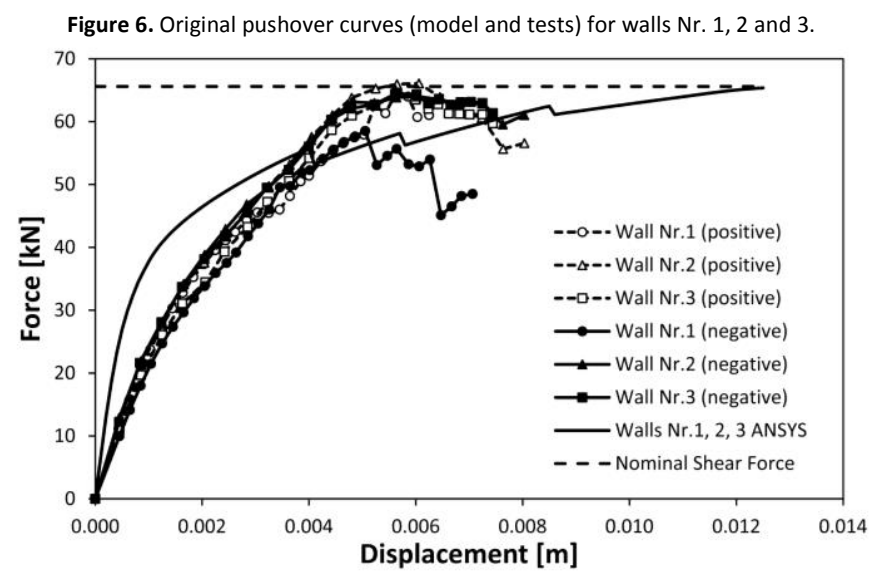

Table 1. Main results for bilinear pushover curve of wall Nr. 1.

\begin{tabular}{lccccc}
\hline Parameter & ANSYS & Test $(+)$ & Error \% & Test $(-)$ & Error \% \\
\hline $\mathrm{F}_{\max }(\mathrm{kN})$ & 58.60 & 56.90 & 2.99 & 53.10 & 10.36 \\
$\mathrm{D}_{\max }(\mathrm{m})$ & 0.0125 & 0.0062 & 100.08 & 0.0071 & 77.00 \\
$\mathrm{D}_{\mathrm{e}}(\mathrm{m})$ & 0.0017 & 0.0032 & -47.98 & 0.0033 & -49.43 \\
$\mathrm{~K}_{\mathrm{e}}(\mathrm{kN} / \mathrm{m})$ & 35,269 & 17,815 & 97.98 & 16,162 & 118.23 \\
$\mu$ & 7.52 & 1.96 & 284.61 & 2.15 & 250.01 \\
\hline
\end{tabular}

Table 2. Main results for bilinear pushover curve of wall Nr. 2.

\begin{tabular}{lccccc}
\hline Parameter & ANSYS & Test $(+)$ & Error \% & Test $(-)$ & Error \% \\
\hline$F_{\max }(\mathrm{kN})$ & 58.60 & 61.90 & -5.33 & 60.70 & -3.46 \\
$D_{\max }(\mathrm{m})$ & 0.0125 & 0.0080 & 55.62 & 0.0080 & 55.67 \\
$\mathrm{D}_{\mathrm{e}}(\mathrm{m})$ & 0.0017 & 0.0035 & -52.67 & 0.0032 & -47.73 \\
$\mathrm{~K}_{\mathrm{e}}(\mathrm{kN} / \mathrm{m})$ & 35,269 & 17,634 & 100.00 & 19,097 & 84.68 \\
$\mu$ & 7.52 & 2.29 & 228.77 & 2.53 & 197.81 \\
\hline
\end{tabular}

Table 3. Main results for bilinear pushover curve of wall Nr. 3 .

\begin{tabular}{lccccc}
\hline Parameter & ANSYS & Test $(+)$ & Error \% & Test (-) & Error \% \\
\hline$F_{\max }(k N)$ & 58.60 & 61.20 & -4.25 & 61.20 & -4.25 \\
$D_{\max }(\mathrm{m})$ & 0.0125 & 0.0074 & 68.02 & 0.0074 & 67.99 \\
$\mathrm{D}_{\mathrm{e}}(\mathrm{m})$ & 0.0017 & 0.0037 & -55.69 & 0.0033 & -49.95 \\
$\mathrm{~K}_{\mathrm{e}}(\mathrm{kN} / \mathrm{m})$ & 35,269 & 16,320 & 116.10 & 18,435 & 91.32 \\
$\mu$ & 7.52 & 1.98 & 279.21 & 2.24 & 235.65 \\
\hline
\end{tabular}




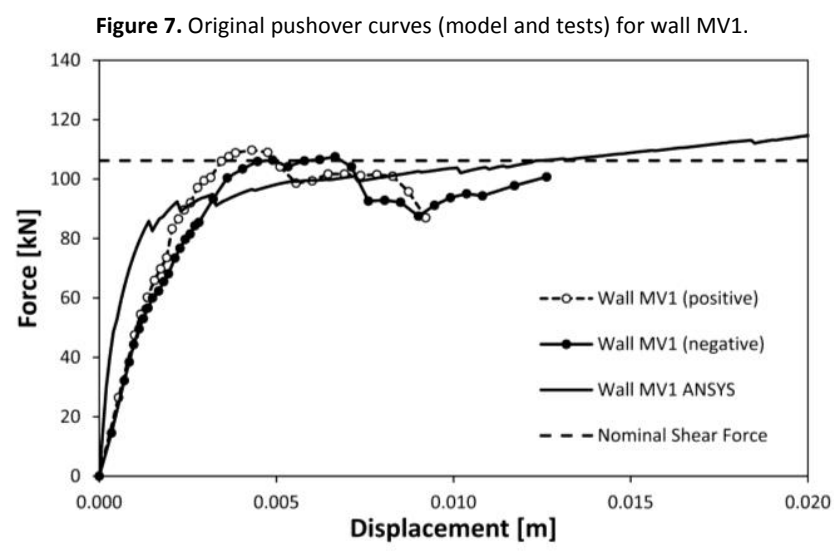

Table 4. Main results for bilinear pushover curve of wall MV1.

\begin{tabular}{lccccc}
\hline Parameter & ANSYS & Test $(+)$ & Error \% & Test (-) & Error \% \\
\hline$F_{\max }(\mathrm{kN})$ & 105.20 & 101.40 & 3.75 & 98.40 & 6.91 \\
$\mathrm{D}_{\max }(\mathrm{m})$ & 0.0228 & 0.0092 & 147.42 & 0.0126 & 80.55 \\
$\mathrm{D}_{\mathrm{e}}(\mathrm{m})$ & 0.0013 & 0.0024 & -45.80 & 0.0027 & -52.05 \\
$\mathrm{~K}_{\mathrm{e}}(\mathrm{kN} / \mathrm{m})$ & 81,028 & 42,328 & 91.43 & 36,343 & 122.95 \\
$\mu$ & 17.56 & 3.85 & 356.53 & 4.66 & 276.51 \\
\hline
\end{tabular}

Figure 8. Original pushover curves (model and tests) for wall MV2.

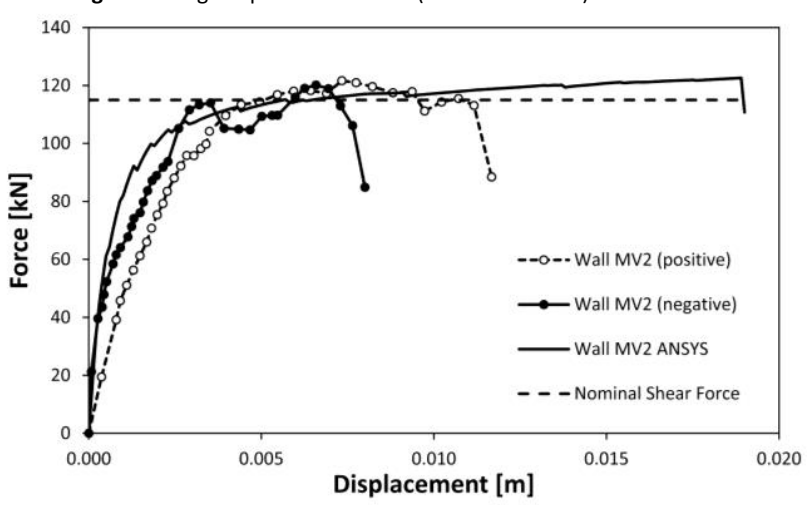

Table 5. Main results for bilinear pushover curve of wall MV2.

\begin{tabular}{lccccc}
\hline Parameter & ANSYS & Test $(+)$ & Error \% & Test $(-)$ & Error \% \\
\hline$F_{\max }(k N)$ & 116.10 & 114.30 & 1.57 & 110.70 & 4.88 \\
$D_{\max }(\mathrm{m})$ & 0.0190 & 0.0117 & 62.80 & 0.0080 & 137.50 \\
$\mathrm{D}_{\mathrm{e}}(\mathrm{m})$ & 0.0012 & 0.0030 & -59.37 & 0.0019 & -37.54 \\
$\mathrm{~K}_{\mathrm{e}}(\mathrm{kN} / \mathrm{m})$ & 96,252 & 38,499 & 150.01 & 57,324 & 67.91 \\
$\mu$ & 15.75 & 3.93 & 300.71 & 4.14 & 280.24 \\
\hline
\end{tabular}

Figure 9. Original pushover curves (model and tests) for wall MV3.

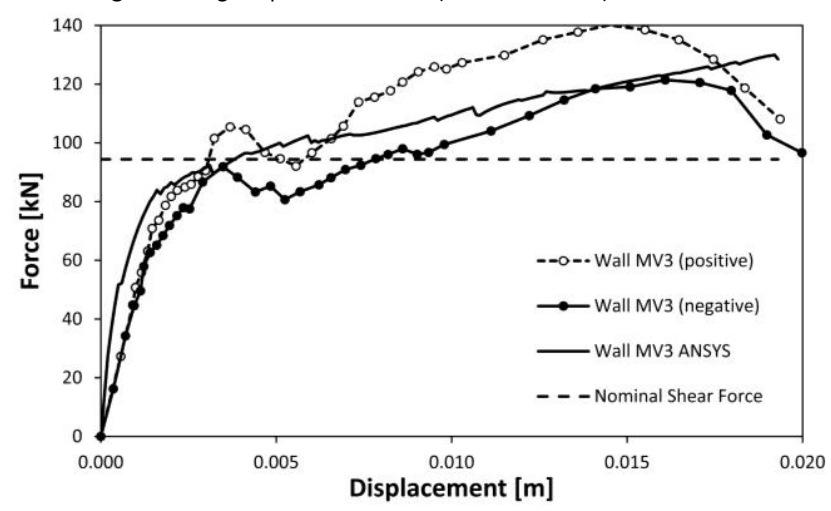


Table 6. Main results for bilinear pushover curve of wall MV3.

\begin{tabular}{lccccc}
\hline Parameter & ANSYS & Test $(+)$ & Error \% & Test $(-)$ & Error \% \\
\hline$F_{\max }(k N)$ & 110.90 & 121.70 & -8.87 & 103.50 & 7.15 \\
$D_{\max }(\mathrm{m})$ & 0.0193 & 0.0194 & -0.31 & 0.0200 & -3.41 \\
$\mathrm{D}_{\mathrm{e}}(\mathrm{m})$ & 0.0019 & 0.0032 & -41.75 & 0.0029 & -34.58 \\
$\mathrm{~K}_{\mathrm{e}}(\mathrm{kN} / \mathrm{m})$ & 59,068 & 37,756 & 56.45 & 36,062 & 63.79 \\
$\mu$ & 10.28 & 6.01 & 71.16 & 6.96 & 47.66 \\
\hline
\end{tabular}

Figure 10. Original pushover curves (model and tests) for walls MLC-T1-01 and MLC-T1-02.

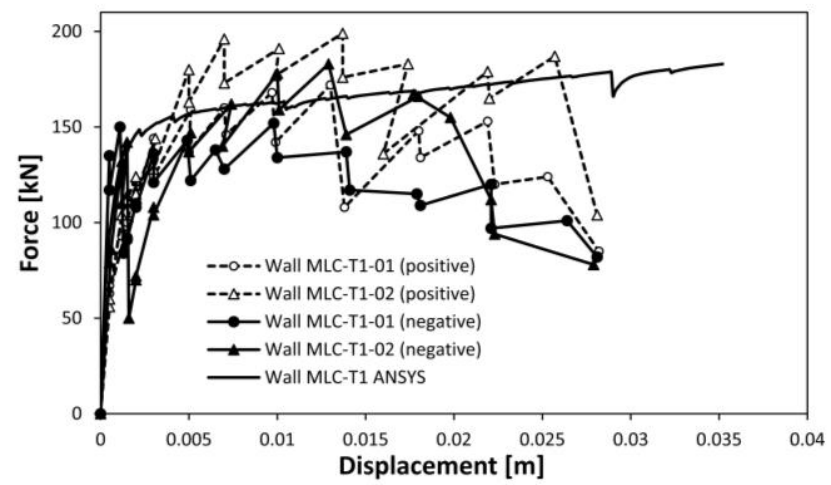

Table 7. Main results for bilinear pushover curve of walls MLC-T1-01.

\begin{tabular}{lccccc}
\hline Parameter & ANSYS & Test $(+)$ & Error \% & Test $(-)$ & Error \% \\
\hline $\mathrm{F}_{\max }(\mathrm{kN})$ & 168.08 & 141.80 & 18.49 & 121.60 & 38.22 \\
$\mathrm{D}_{\max }(\mathrm{m})$ & 0.0352 & 0.0282 & 24.82 & 0.0281 & 25.27 \\
$\mathrm{D}_{\mathrm{e}}(\mathrm{m})$ & 0.0011 & 0.0023 & 50.44 & 0.0004 & 153.13 \\
$\mathrm{~K}_{\mathrm{e}}(\mathrm{kN} / \mathrm{m})$ & 150,100 & 62,774 & 139.11 & 274,887 & 153.13 \\
$\mu$ & 31.43 & 12.48 & 151.88 & 63.52 & 50.51 \\
\hline
\end{tabular}

Table 8. Main results for bilinear pushover curve of walls MLC-T1-02.

\begin{tabular}{lccccc}
\hline Parameter & ANSYS & Test $(+)$ & Error \% & Test $(-)$ & Error \% \\
\hline$F_{\max }(\mathrm{kN})$ & 168.08 & 192.60 & 12.71 & 146.40 & 14.81 \\
$\mathrm{D}_{\max }(\mathrm{m})$ & 0.0352 & 0.0281 & 25.27 & 0.0279 & 26.16 \\
$\mathrm{D}_{\mathrm{e}}(\mathrm{m})$ & 0.0011 & 0.0029 & 60.77 & 0.0012 & 7.18 \\
$\mathrm{~K}_{\mathrm{e}}(\mathrm{kN} / \mathrm{m})$ & 150,101 & 67,458 & 122.51 & 121,360 & 23.68 \\
$\mu$ & 31.43 & 9.84 & 219.31 & 23.13 & 35.92 \\
\hline
\end{tabular}

The proposed model showed good agreement with the results of the laboratory tests and may be considered as appropriate to represent the non-linear behaviour of a single masonry wall, taking into account the alternatives of reinforced and confined masonry.

One of the most important advantages of the proposed model is that it can represent a wide variety of different wall configurations in terms of materials quality (bricks, mortar and interface between brick and mortar) and geometry (general and specific).

Observing the results of the proposed model, it is easy to notice that, in general, force (Fmax) is much better approached than displacements (De and Dmax). These results for displacements determine the quality of the results for stiffness $(\mathrm{Ke})$ and ductility $(\mu)$. This situation may be explained because the quality of the materials is usually defined as the compression or tension strength of the material, which is directly related with stress or force. The properties of the materials which are directly related to displacement (elasticity module $E$ and yielding, ultimate or fracture deformations or displacements) are only estimated according to the recommendations found on codes or other studies. 
Finally, the results may vary considerably if the mechanical properties of the materials were estimated accurately taking into account specific laboratory tests, especially for those parameters which were estimated only from the recommendations given in literature.

ANSYS. (2009). Theory Reference for the Mechanical APDL and Mechanical Applications. Canonsburg, Pennsylvania, U.S.A.: SAS IP, Inc.

Campbell, J. (2012). Numerical Model for Nonlinear Analysis of Masonry Walls. Rheinisch-Westfälische Technische Hochschule Aachen. Retrieved from http://dspace2.conicyt.cl/handle/10533/89166

Díaz, L., Arancibia, I., Vicencio, M., Durán, M., \& Campbell, J. (2005). Ensayos de Muros de Albañilería Armada de Esbelteces Mayores a Uno Solicitados a Carga Cíclica. In Congreso Chileno de Sismología e Ingeniería Antisísmica IX Jornadas. Concepción, Chile: ACHISINA.

DIN. (1998). EN 1052-1 Prüfverfahren für Mauerwerk. Berlin, Deutschland: Deutsches Institut für Normung.

FEMA. (1997). NEHRP Guidelines for the Seismic Rehabilitation of Buildings. Washington, D.C., USA: Federal Emergency Management Agency.

Galleguillos, M., Valenzuela, C., \& Díaz, L. (2010). Estudio Experimental de Muros de Albañilería Confinada a Escala Natural Solicitados a Carga Cíclica Horizontal. In Congreso Chileno de Sismología e Ingeniería Antisísmica IX Jornadas. Santiago, Chile: ACHISINA.

INN. (1997). NCh2123.0f97 - Albañilería Armada - Requisitos de Diseño Estructural. Santiago, Chile: Instituto Nacional de Normalización.

INN. (2003). NCh1928.0f1993 Mod2003 - Albañilería Armada - Requisitos para el Diseño y Cálculo. Santiago, Chile: Instituto Nacional de Normalización.

Irmschler, H.-J., Schubert, P., \& Jäger, W. (2004). Mauerwerk Kalender 2004. (H.-J. Irmschler, P. Schubert, \& W. Jäger, Eds.). Wiley-VCH Verlag GmbH.

Kaushik, H. B., Rai, D. C., \& Jain, S. K. (2007). Stress-Strain Characteristics of Clay Brick Masonry under Uniaxial Compression. Journal of Materials in Civil Engineering, 19(9), 728-739. https://doi.org/10.1061/(ASCE)0899-1561(2007)19:9(728)

López, J., Oller Martínez, S., \& Oñate, E. (1998). Cálculo del Comportamiento de la Mampostería Mediante Elementos Finitos. Barcelona, España: Centro Internacional de Métodos Numéricos en Ingeniería.

Lourenço, P. B. (1996). Computational strategies for masonry structures. PhD Thesis. Delft University Press, Delft, The Netherlands. https://doi.org/ISBN 90-407-1221-2

Lüders, C. (1990). Técnicas de reparación y refuerzo de muros de albañilería armada. Santiago, Chile: Pontificia Universidad Católica de Chile.

Page, A. (1978). Finite element model for masonry. Journal of the Structural Division, (August 1978), 1267-1285.

Page, A., Kleeman, P., \& Dhanasekar, M. (1985). An in-plane finite element model for brick masonry. In S. Anand (Ed.), New analysis techniques for structural masonry (p. 18). Chicago, Illinois, USA: American Society of Civil Engineers.

Santa María, H., Hube, M. A., Rivera, F., Yepes-Estrada, C., \& Valcárcel, J. A. (2017). Development of national and local exposure models of residential structures in Chile. Natural Hazards, 86, 55-79. https://doi.org/10.1007/s11069-016-2518-3

The Masonry Society. (2003). Masonry designer's guide - Fourth edition (Fourth Edi). Colorado, U.S.A.: The Masonry Society.

Yáñez, F., Astroza, M., Holmberg, A., \& Ogaz, O. (2004). Behavior of confined masonry shear walls with large openings. 13th World Conference on Earthquake Engineering, (3438). Retrieved from http://www.iitk.ac.in/nicee/wcee/article/13_3438.pdf 